\title{
Effect of Moisture on Adsorption Isotherms and Adsorption Capacities of $\mathrm{CO}_{2}$ on Coals
}

\author{
Ekrem Ozdemir*, ${ }^{\dagger, \ddagger}$ and Karl Schroeder ${ }^{\dagger}$ \\ National Energy Technology Laboratory, U.S. Department of Energy, \\ P.O. Box 10940, Pittsburgh, Pennsylvania 15236 and Department of Chemical Engineering, Izmir Institute \\ of Technology, Gulbahce Campus, Urla, Izmir, Turkey
}

Received December 24, 2008. Revised Manuscript Received February 20, 2009

\begin{abstract}
The effect of moisture on the adsorption isotherms and adsorption capacities of $\mathrm{CO}_{2}$ on Argonne Premium coals has been investigated. In some experiments a small hysteresis was observed between the adsorption and desorption isotherms. The hysteresis was absent or negligible for high-rank and as-received coals but was discernible for lower rank and dried coals. An equation that accounted for the volumetric changes when an adsorbate alters the structure of an adsorbent was employed to interpret the data. The best-fit solutions indicate that the coal volume decreases upon drying. The microscopic shrinkage estimated using helium expansion was greater than the shrinkage reported using the bed-height technique. The microscopic shrinkage was $5-10 \%$ for low-moisture medium and high-rank coals and up to $40 \%$ for low-rank coals having higher moisture contents. The $\mathrm{CO}_{2}$ swelling of coals during adsorption isotherm measurements was estimated to be about the same as the shrinkage that occurred during the moisture loss. The adsorption capacity, isosteric heat of adsorption, average pore size, and surface area of the as-received (moist) and dried Argonne coals were estimated after accounting for the volume changes. The isosteric heat of adsorption of $\mathrm{CO}_{2}$ was found to be between 23 and $25 \mathrm{~kJ} / \mathrm{mol}$ for as-received coals and between 25 and $27 \mathrm{~kJ} / \mathrm{mol}$ for dried coals, regardless of the rank. The degree of drying was shown to affect the adsorption capacity and the calculated surface area. For dried coals, the adsorption capacity showed the typical ' $U$-shape' dependence on rank whereas the as-received coals displayed a more linear dependence. A relationship is proposed to quantify the effect of moisture on the adsorption capacity. The mechanism of $\mathrm{CO}_{2}$ adsorption on moist coals and the implications of the lower adsorption capacity of wet coals to coal seam sequestration of $\mathrm{CO}_{2}$ are presented.
\end{abstract}

\section{Introduction}

Sequestration of carbon dioxide $\left(\mathrm{CO}_{2}\right)$ in unmineable coal seams is a possible strategy for mitigating greenhouse gas emissions. ${ }^{1}$ Adsorption on a solid, immobile matrix that is stable over geologic times is an important advantage of coal seam sequestration of $\mathrm{CO}_{2}$. The enhancement of the production of coalbed methane (CBM) is another advantage that reduces the sequestration cost, and in most cases, it is profitable. ${ }^{2}$ However, the adsorption capacity and stability of the adsorbed $\mathrm{CO}_{2}$ are affected by the nature of the coal and the environment in which it is placed. Pressure, temperature, coal rank, coal moisture content, and changes in the $\mathrm{pH}$ of the coalbed water are factors that may limit or enhance the extent of adsorption. ${ }^{3}$ Safety issues associated with the mining of gassy coal seams have prompted studies of methane $\left(\mathrm{CH}_{4}\right)$ adsorption and the effect of moisture on the $\mathrm{CH}_{4}$ adsorption capacity of coal. ${ }^{4-6}$ There have been a

* To whom correspondence should be addressed. Telephone: $+90(232) 750$ 6685. Fax: +90(232)750 6645. E-mail: ekremozdemir@iyte.edu.tr.

$\dagger$ U.S. Department of Energy.

$\ddagger$ Izmir Institute of Technology.

(1) White, C. M.; Smith, D. H.; Jones, K. L.; Goodman, A. L.; Jikich, S. A.; LaCount, R. B.; Dubose, S. B.; Ozdemir, E.; Morsi, B. I.; Schroeder, K. T. Energy Fuels 2005, 19, 659-724.

(2) Stevens, S. H.; Gale, J. Oil Gas J. 2000, 98, 40-44.

(3) Schroeder, K.; Ozdemir, E.; Morsi, B. I. Sequestration of Carbon Dioxide in Coal Seams. First National Carbon Sequestration Conference Proceedings. DOE/NETL, 2001, 1-10.

(4) Levy, J. H.; Day, S. J.; Killingley, J. S. Fuel 1997, 76, 813-819.

(5) Bustin, R. M.; Clarkson, C. R. Int. J. Coal Geol. 1998, 38, 3-26.

(6) Moffat, D. H.; Weale, K. E. Fuel 1955, 34, 449-462. few studies of the $\mathrm{CO}_{2}$ adsorption on coal and of the parameters that affect the stability of the adsorbed $\mathrm{CO}_{2}$ under in-seam conditions..$^{7-14}$ One of these parameters is the moisture content of the coal. The fact that the $\mathrm{CH}_{4}$ adsorption capacity of coal decreases with increasing moisture content is well established; $4,15,16$ the effect of moisture on the $\mathrm{CO}_{2}$ adsorption isotherms and adsorption capacity of coals with various ranks is of special interest.

Moisture plays an important role in the adsorption of gases on coal, and there have been some efforts to quantify the effect of moisture on the adsorption capacity. ${ }^{17,18}$ Joubert et al. ${ }^{19}$ showed a linear decrease in $\mathrm{CH}_{4}$ adsorption with increasing moisture content up to a critical value, which appeared to be the equilibrium moisture content as estimated at $30{ }^{\circ} \mathrm{C}$ and $96 \%$ relative humidity. For moisture contents greater than the critical

(7) Dutta, P.; Harpalani, S.; Prusty, B. Fuel 2008, 87, 2023-2036.

(8) Day, S.; Fry, R.; Sakurovs, R. Int. J. Coal Geol. 2008, 74, 41-52.

(9) Romanov, V.; Soong, Y. Energy Fuels 2008, 22, 1167-1169.

(10) Romanov, V. N.; Goodman, A. L.; Larsen, J. W. Energy Fuels 2006, 20, 415-416.

(11) Karacan, C. O. Energy Fuels 2003, 17, 1595-1608.

(12) Sakurovs, R.; Day, S.; Weir, S.; Duffy, G. Energy Fuels 2007, 21, 992-997.

(13) Siemons, N.; Busch, A. Int. J. Coal Geol. 2007, 69, 229-242.

(14) Goodman, A. L.; Campus, L. A.; Schroeder, K. T. Energy Fuels 2005, 19, 471-476.

(15) Joubert, J. I.; Grein, C. T.; Bienstock, D. Fuel 1972, 52, 185.

(16) Yee, D.; Seidle, J. P.; Hanson, W. P. Gas Sorption on Coal and Measurement of Gas Content. Law, B. E., Rice, D. D., Eds., Hydrocarbons from Coal. Am. Assoc. Pet. Geol.: Tulsa, OK, 1993, 159, 184. 
value, there was no further reduction in $\mathrm{CH}_{4}$ adsorption. This was interpreted as the excess moisture was located on the external surface of the coal and did not affect the sorption further by blocking the pores. Levy et al. ${ }^{4}$ showed that the adsorption capacity of $\mathrm{CH}_{4}$ on coals increased linearly from 12 to $26 \mathrm{~mL} / \mathrm{g}$ as the moisture content decreased from $4 \%$ to $0.5 \%$. Ettinger et al. $^{20}$ developed a simple analytical relationship (eq 1) to correct the effect of moisture on the adsorption capacity of $\mathrm{CH}_{4}$ on coal

$$
\frac{n_{\mathrm{w}}}{n_{\mathrm{d}}}=\frac{1}{1+A m}
$$

where $n_{\mathrm{w}}$ and $n_{\mathrm{d}}$ are the adsorbed amount of $\mathrm{CH}_{4}$ on the wet and dry coal at any pressure, respectively, $m$ is the percent moisture content, and $A$ is a coefficient. The value of the coefficient $(A)$ has been reported to be 0.39 by Levy et al., ${ }^{4}$ 0.31 by Ettinger et al., ${ }^{20}$ and 0.27 by Joubert et al. ${ }^{19}$ Joubert noted, however, that the coefficient was pressure dependent and increased from 0.19 to 0.28 as the pressure decreased from 6 to $1 \mathrm{MPa}$ and extrapolated to 0.314 at $0.1 \mathrm{MPa}$, in good agreement with Ettinger. ${ }^{20}$ The Levy data was obtained at 5 MPa. Similar data for $\mathrm{CO}_{2}$ is lacking, although recent studies have been published on moisture-equilibrated coals. ${ }^{17,18}$

While it is tempting to interpret some of the isotherm data as a simple competition between moisture and adsorbing gas $\left(\mathrm{CH}_{4}\right.$ or $\left.\mathrm{CO}_{2}\right)$, moisture can play a role in the 3-dimensional structure of the organic coal matrix..$^{21-23}$ Coal has a colloidal gel-like structure that can shrink and swell in response to loss and gain of moisture ${ }^{23}$ or to adsorption and desorption of gases, ${ }^{24,25}$ vapors, ${ }^{26,27}$ and solvents. ${ }^{28}$ Suuberg et al. ${ }^{23}$ showed that coals shrink when dried, even bituminous coals. For the lower rank coals, a volumetric shrinkage of $25-30 \%$ was measured. Hayashi et al. ${ }^{29}$ showed that the removal of moisture caused the coal to shrink and the pores to collapse. Mahajan's interpretation ${ }^{30}$ has been that coals have an aperture-cavity type porosity. Entrance to the pore system is governed by the aperture size, and extent of adsorption is determined by the cavity volume.

In order to predict the $\mathrm{CO}_{2}$ storage capacity of a candidate coal seam and to model its long-term stability, the "intrinsic"

(17) Goodman, A. L.; Busch, A.; Bustin, M.; Chikatamarla, L.; Day, S.; Duffy, G. J.; Fitzgerald, J. E.; Gasem, K. A. M.; Gensterblum, Y.; Hartman, C.; Jing, C.; Krooss, B. M.; Mohammed, S.; Pratt, T.; Robinson, R. L.; Romanov, V.; Sakurovs, R.; Schroeder, K.; White, C. M. Int. J. Coal Geol. 2007, 72, 153-164.

(18) Day, S.; Sakurovs, R.; Weir, S. Int. J. Coal Geol. 2008, 74, 203-

(19) Joubert, J. I.; Grein, C. T.; Bienstock, D. Fuel 1974, 53, 186-190.

(20) Ettinger, I. L.; Lidin, G. D.; Dmitrev, A. M.; Zhupakhina, E. A. Systematic Handbook for the Determination of the Methane Content of Coal Seams from the Seam Pressure of the Gas and the Methane Capacity of the Coal; U.S. Bureau of Mines Translation No. 1505/National Board Translation No. A.1606/SEH: Moscow, 1958.

(21) Evans, D. G. Fuel 1973, 52, 186-190.

(22) Deevi, S. C.; Suuberg, E. M. Fuel 1987, 66, 454-460.

(23) Suuberg, E.; Otake, Y.; Yun, Y.; Deevi, S. Energy Fuels 1993, 7, 384-392.

(24) Reucroft, P. J.; Patel, H. Fuel 1986, 65, 816-820.

(25) St.George, J. D.; Barakat, M. A. Int. J. Coal Geol. 2001, 45, $105-$ 113.

(26) Shimizu, K.; Takanohashi, T.; Iino, M. Energy Fuels 1998, 12, 891-896.

(27) Takanohashi, T.; Terao, Y.; Yoshida, T.; Iino, M. Energy Fuels 2000, 14, 915-919.

(28) Otake, Y.; Suuberg, E. M. Fuel 1989, 68, 1609-1612.

(29) Hayashi, J.; Norinaga, K.; Kudo, N.; Chiba, T. Energy Fuels 2001, $15,903-909$.

(30) Mahajan, O. P. Adsorption and Pore Structure and Coal-Water Interactions. In Sample Selection, Aging and Reactivity of Coal; Klein, R., Ed.; Wiley, NY, 1989. adsorption capacity of the organic matrix of the coal and how this capacity may change with changes in the sequestration environment must be known accurately. Yet, even though coal is known to be an elastic material, it is generally treated as a rigid solid in the evaluation of the adsorption isotherm data using the traditional adsorption isotherm models. ${ }^{31-34}$ Phenomena such as absorption to form solid solutions and swelling that occur when coal is in contact with adsorbing gases, ${ }^{24,35,36}$ vapors, ${ }^{26,27}$ and solvents ${ }^{37}$ do not fit the rigid-solid model. A number of $\mathrm{CO}_{2}$ sorption studies have appeared in recent years that attempt to interpret the isotherm data by taking the volume changes into account. $7,8,10,26,27,38-41$ The influence of volume changes on the shape of the adsorption isotherms needs to be accounted for; otherwise, the interpretation of the isotherms will be erronous. ${ }^{10}$ An expression that incorporates the solid solution effect as well as the effect of coal swelling on the $\mathrm{CO}_{2}$ adsorption isotherm has been published. ${ }^{39}$ Its generalized form is given in eq 2

$$
n^{\mathrm{ex}}=\left(1-\frac{\rho}{\rho^{\mathrm{a}}}\right) n^{\mathrm{abs}}+\rho \Delta V
$$

where $n^{\text {ex }}$ is the experimentally measured amount of adsorption, $\rho$ is the density of the gas phase, $\rho^{\mathrm{a}}$ is the density of the adsorbed phase, $n^{\text {abs }}$ is the absolute adsorption or the actual amount of gas adsorbed, and $\Delta V$ is the unaccounted for volume due to the gas solubility in the coal matrix, the coal swelling, and any over- or underestimation of the void volume $\left(V_{\mathrm{o}}\right)$ in the sample cell due to the assumptions underlying the choice of helium as the reference gas in the adsorption experiments. ${ }^{42-44}$ The purpose of this study is to investigate the effect of the moisture content on the adsorption isotherms and the adsorption capacity of $\mathrm{CO}_{2}$ on coals accounting for volumetric effects.

\section{Experimental Section}

2.1. Coal Samples and Adsorption Apparatus. Coals were obtained from the Argonne National Laboratory through the Premium Coal Sample Program. ${ }^{45}$ The proximate analyses are shown in Table $1 .{ }^{46}$ Because coals rapidly and irreversibly adsorb atmospheric oxygen ${ }^{47}$ efforts were devoted to maintain an oxygenfree environment. Sample handling was performed in an inert gas (helium) flushed glovebag under a positive pressure of He. Vials

(31) Clarkson, C. R.; Bustin, R. M.; Levy, J. H. Appl. Catal. A: Gen. 1997, 35, 1689-1705.

(32) Clarkson, C. R.; Bustin, R. M. Fuel 1999, 78, 1333-1344.

(33) Degance, A. E.; Morgan, W. D.; Yee, D. Fluid Phase Equilib. 1993, $82,215-224$.

(34) Mahajan, O. P. Appl. Catal. A: Gen. 1991, 29, 735-742.

(35) Reucroft, P. J.; Sethuraman, A. R. Energy Fuels 1987, 1, 72-75.

(36) Walker, P. L.; Verma, S. K.; Rivera-Utrilla, J.; Khan, R. Fuel 1988, 67, 719-726.

(37) Otake, Y.; Suuberg, E. M. Fuel 1998, 77, 901-904.

(38) Milewska-Duda, J.; Duda, J.; Nodzenski, A.; Lakatos, J. Langmuir 2000, 16, 5458-5466.

(39) Ozdemir, E.; Morsi, B. I.; Schroeder, K. Langmuir 2003, 19, 9764 9773.

(40) Ozdemir, E.; Schroeder, K.; Morsi, B. I. Am. Chem. Soc., Fuel Chem Div. Prepr. 2002, 47, 12-13.

(41) Ozdemir, E.; Morsi, B. I.; Schroeder, K. Fuel 2004, 83, 10851094.

(42) Sircar, S. Ind. Eng. Chem. Res. 1999, 38, 3670-3682.

(43) Malbrunot, P.; Vidal, D.; Vermesse, J. Langmuir 1997, 13, 539544.

(44) Larsen, J. W.; Hall, P.; Wernett, P. C. Energy Fuels 1995, 9, 324330.

(45) Vorres, K. S. Energy Fuels 1990, 4, 420-426.

(46) Vorres, K. S. User's Handbook for the Argonne Premium Coal Sample Program; Argonne National Laboratory, IL, 1993.

(47) Schmidt, L. D. Changes in coal during storage. In Chemistry of Coal Utilization; John Wiley \& Sons, Inc.: New York, 1945; pp 627-676. 
Table 1. Proximate Analyses of the Argonne Premium Coal Samples $^{45}$

\begin{tabular}{llllcrrr}
\hline \multicolumn{1}{c}{ coal sample } & & & \multicolumn{3}{c}{ proximate analysis (wt \%) } \\
\cline { 1 - 3 } \cline { 5 - 6 } \multicolumn{1}{c}{ seam } & state & & rank & moisture & ash $^{a}$ & VM $^{a}$ \\
\hline Pocahontas No. 3 & VA & & low vol. bit. & 0.65 & 4.74 & 18.48 \\
Upper Freeport & PA & & med. vol. bit. & 1.13 & 13.03 & 27.14 \\
Pittsburgh No. 8 & PA & & high vol. bit. & 1.65 & 9.10 & 37.20 \\
Lewiston-Stockton & WV & & high vol. bit. & 2.42 & 19.36 & 29.44 \\
Blind Canyon & UT & & high vol. bit. & 4.63 & 4.49 & 43.72 \\
Illinois No. 6 & IL & & high vol. bit. & 7.97 & 14.25 & 36.86 \\
Wyodak-Anderson & WY & & subbit. & 28.09 & 6.31 & 32.17 \\
Beulah-Zap & ND & & lignite & 32.24 & 6.59 & 30.45
\end{tabular}

${ }^{a}$ Dry basis.

of the Argonne Premium coals were opened only after they were well mixed in accordance with the provided mixing instructions. ${ }^{46}$ Samples were removed from the glovebag only after they had been placed in the sample cell and capped.

Measurements were made using a high-pressure manometric gas adsorption apparatus. A description of the apparatus has been given elsewhere. ${ }^{39,41}$ Briefly, the apparatus consisted of a reservoir of approximately $13 \mathrm{~mL}$ and a sample cell of about $6 \mathrm{~mL}$; both were submerged within a temperature-controlled bath $\left( \pm 0.1{ }^{\circ} \mathrm{C}\right)$. The pressure transducers for each sample cell were calibrated in the pressure range studied. Cell volumes were estimated by the Heexpansion method. An ISCO syringe pump was used to deliver pressurized $\mathrm{He}$ or $\mathrm{CO}_{2}$ with a purity of $99.997 \%$ and $99.999 \%$, respectively.

2.2. Determination of Volume of Coals and Void Volume in Sample Cell. Volumes of as-received and dried Argonne Premium coals and the void volume in the sample cell were measured in situ by the He-displacement method. A $0.6-1.2 \mathrm{~g}$ aliquot of as-received coal was placed in the sample cell and degassed under vacuum for $5 \mathrm{~min}$ in order to remove any adsorbed gases. Then, the volume of the coal sample and the gas accessible void volume in the sample cell were measured at $22{ }^{\circ} \mathrm{C}$ by introducing $\mathrm{He}$ at pressures up to $3 \mathrm{MPa}$ in the same way as will be described for $\mathrm{CO}_{2}$ in the isotherm measurement method. The volumes of the dried coals were measured in a similar fashion after the as-received coals were dried in situ at the desired temperature under vacuum. The shrinkage of coals upon drying was calculated as the difference between the helium-measured volumes of the asreceived and dried coals.

2.3. Moisture Content. In order to obtain coal samples with various moisture contents, as-received samples were dried in situ in the adsorption apparatus. Each coal sample was vacuum dried individually at $22,22,45,80$, or $97{ }^{\circ} \mathrm{C}$ for $4,20,10,36$, or $5 \mathrm{~h}$, respectively. After drying, the coals were allowed to equilibrate for $2-3 \mathrm{~h}$ at $22{ }^{\circ} \mathrm{C}$ prior to the isotherm measurement. The moisture content of each coal sample was determined using thermal gravimetric analysis (TGA) after the adsorption isotherm measurement was complete. TGA drying experiments were conducted on $23 \mathrm{mg}$ samples, at $105^{\circ} \mathrm{C}$ for $60 \mathrm{~min}$. The volume of the moisture removed during the in situ drying was calculated by subtracting the moisture content of the dried coal from the moisture content of as-received coal assuming a density of $1 \mathrm{~g} / \mathrm{cm}^{3}$.

2.4. Isotherm Measurement Method. After removing the helium under vacuum, the reservoir was pressurized with $\mathrm{CO}_{2}$. After allowing $10 \mathrm{~min}$ for thermal equilibration, although a stable temperature reading was achieved in about $3 \mathrm{~min}$, a portion of the $\mathrm{CO}_{2}$ was transferred from the reservoir to the sample cell. The pressure and temperature were monitored in both cells to verify thermal and adsorption equilibration. Although longer equilibration times are required for chunks of coal, ${ }^{48}$ the $\mathrm{CO}_{2}$ adsorption was fast for these coals with particle sizes of less than $150 \mu \mathrm{m}$. In initial tests, it was found that the pressure was stable after $20-30 \mathrm{~min}$

(48) Wolf, K.-H. A. A.; Barzandji, O. H.; Bruining, H.; Ephraim, R. $\mathrm{CO}_{2}$ Injection In and $\mathrm{CH}_{4}$ Production From Coal Seams: Laboratory Experiments and Image Analysis For Simulations. First National Carbon Sequestration Conference Proceedings. DOE/NETL, 2001, 1-13. and did not change further in experiments lasting up to $20 \mathrm{~h}$. Thus, a 20-30 min equilibration time was sufficient for the adsorption of $\mathrm{CO}_{2}$ to reach equilibrium. At equilibrium, the amount of $\mathrm{CO}_{2}$ within both the reference and the sample cell was calculated using the real gas law and the compressibility given by Span and Wagner. ${ }^{49}$ From the mass balance, the difference between the moles of $\mathrm{CO}_{2}$ transferred from the reservoir, $n^{\mathrm{t}}$, and the moles of $\mathrm{CO}_{2}$ calculated to be present in the He-estimated free-gas phase in the sample cell, $V_{\mathrm{o}}$, was considered to be the Gibbs excess adsorption, $n^{\text {ex }}$. The reference cell was then pressurized with additional $\mathrm{CO}_{2}$, and the process was repeated. Adsorption isotherms were plotted as the total amount of excess adsorbed $\mathrm{CO}_{2}, n^{\text {ex }}$, versus the measured equilibrium pressure. The error associated with each data point could be as high as $2 \% .{ }^{41}$

\subsection{Evaluation of the Adsorption Isotherm Data.}

2.5.1. Modeling the Adsorption Isotherm Data. The $\mathrm{CO}_{2}$ adsorption isotherm data were evaluated using eq $2 .{ }^{39,41}$ The Dubinin-Astakhov (D-A) equation, ${ }^{50}$ which assumes a pore-filling mechanism rather than surface coverage, was employed to describe the physical adsorption term, $n^{\text {abs }}$. Substituting the D-A equation for the absolute adsorption term, $n^{\text {abs }}$, in the generalized excess adsorption equation, eq 2 , gives eq 3

$$
n^{\mathrm{ex}}=\left(1-\frac{\rho}{\rho^{\mathrm{a}}}\right) n_{\mathrm{o}} e^{-\left[\frac{R T}{\beta E_{\mathrm{o}}} \ln \left(\frac{P_{s}}{P}\right)\right]^{j}}+\rho \Delta V
$$

where $n_{\mathrm{o}}$ is the adsorption/micropore capacity, $\beta$ is the affinity coefficient between $\mathrm{CO}_{2}$ and coal $\left(\beta=0.35\right.$ for $\left.\mathrm{CO}_{2}\right),{ }^{51} E_{\mathrm{o}}$ is the characteristic heat of adsorption, $j$ is the structural heterogeneity parameter, $P_{\mathrm{s}}$ is the saturation pressure, $R$ is the universal gas constant, and $T$ is the temperature.

The saturation pressure $\left(P_{\mathrm{s}}\right)$ and the density of the adsorbed phase $\left(\rho^{\mathrm{a}}\right)$ were calculated using the relationships suggested by Reid et al. ${ }^{52}$ and Dubinin, ${ }^{53}$ respectively. The calculated values were $P_{\mathrm{s}}=$ $5.886 \mathrm{MPa}$ and $\rho^{\mathrm{a}}=3.866 \mathrm{mmol} / \mathrm{cm}^{3}$ at $22{ }^{\circ} \mathrm{C}$. Curve fitting was performed using the SigmaPlot spreadsheet regression data analysis.

2.5.2. Information Obtained from the Adsorption Isotherm Data. Fitting the excess adsorption isotherm data to eq 3 provides solutions for the $\mathrm{CO}_{2}$ adsorption capacity $\left(n_{\mathrm{o}}\right)$, the characteristic heat of adsorption $\left(E_{\mathrm{o}}\right)$, the Dubinin coefficient $(j)$, and the volumetric changes $(\Delta V)$. Additional calculations provide the surface area, isosteric heat of adsorption, and average pore size.

2.5.2.1. Surface Area. The coal surface area is calculated from the $\mathrm{CO}_{2}$ adsorption capacity using eq 4

$$
S=n_{\mathrm{o}} N \sigma
$$

where $N$ is Avogadro's number $\left(6.02 \times 10^{23} \mathrm{molecules} / \mathrm{mol}\right)$ and $\sigma$ is the cross-sectional area of the adsorbate $\left(0.253 \mathrm{~nm}^{2}\right.$ per molecule of $\left.\mathrm{CO}_{2}\right){ }^{4}$

2.5.2.2. Isosteric Heat of Adsorption. The characteristic heat of adsorption, $E_{0}$, can be related to the isosteric heat of adsorption, $Q_{\text {st }}$, eq 5$)^{54}$ at the fractional filling $\phi$ of $\mathrm{e}^{-1}$ using the enthalpy of vaporization $\Delta H_{\mathrm{v}}$ at the boiling point $\left(17.1548 \mathrm{~kJ} / \mathrm{mol}\right.$ for $\left.\mathrm{CO}_{2}\right) .^{52}$

$$
Q_{\mathrm{st}, \varphi=\mathrm{e}^{-1}}=\Delta H_{\mathrm{v}}+\beta E_{o}
$$

2.5.2.3. Average Pore Size. The Dubinin-Astakhov exponent, $j$, and the characteristic heat of adsorption, $E_{0}$, are related to the

(49) Span, R.; Wagner, W. J. Phys. Chem. Ref. Data 1996, 25, 15091596.

(50) Dubinin, M. M. Porous structure and adsorption properties of active carbons. Chemistry and Physics of Carbon; Marcel Dekker Inc.: New York, 1966; pp 51-120.

(51) Medek, J. Fuel 1977, 56, 131-133.

(52) Reid, R. C.; Prausnitz, J. M.; Sherwood, T. K. The Properties of Gases and Liquids; McGraw Hill: New York, 1977.

(53) Dubinin, M. M. Chem. Rev. 1960, 60, 234-241.

(54) Aoshima, M.; Fukasawa, K.; Kaneko, K. J. Colloid Interface Sci. 2000, 222, 179-183. 
(a)

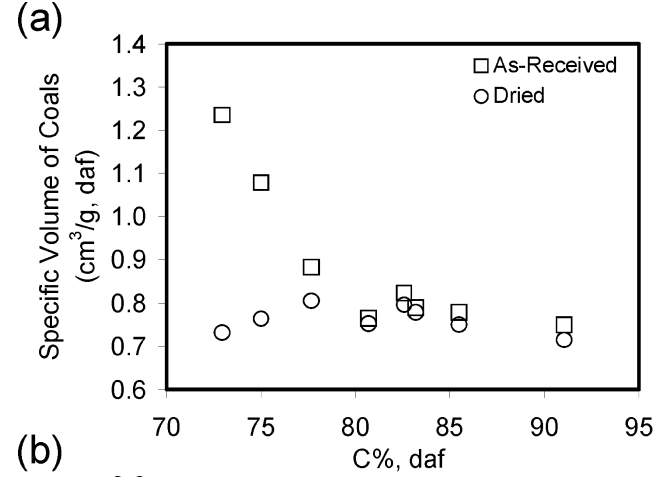

(b)

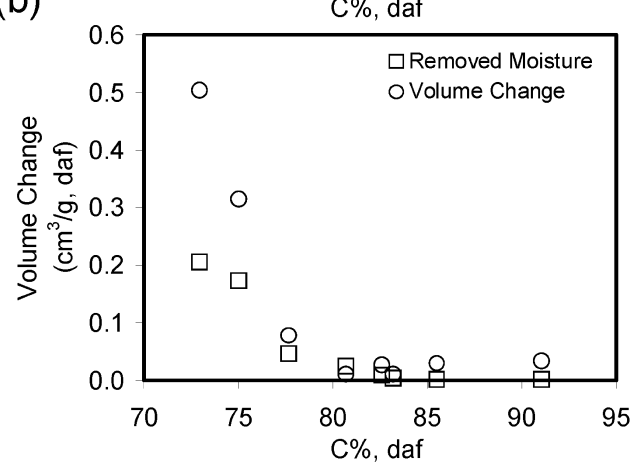

(c)

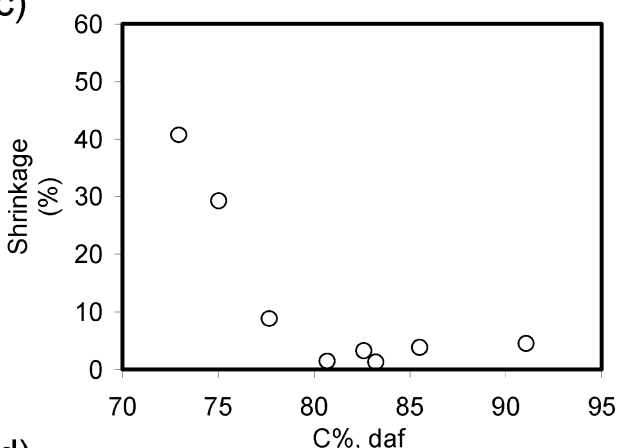

(d)

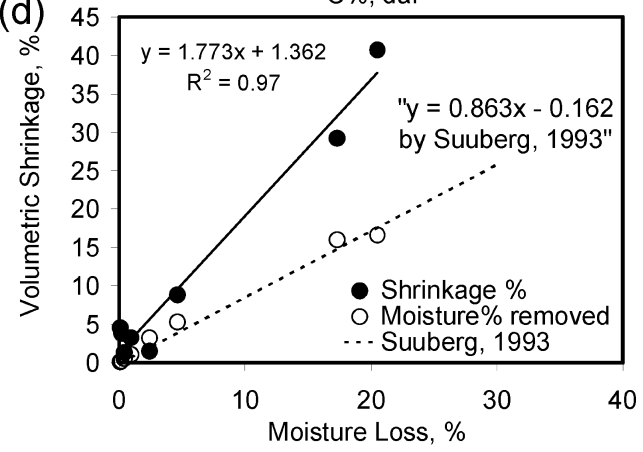

Figure 1. Volumetric changes due to drying of coals. (a) Volumes of as-received and dried (at $80{ }^{\circ} \mathrm{C}$ for 36 h) Argonne coals. (b) Volume of water removed and volume change of dried coals. (c) Percent shrinkage. (d) Comparison of percent volumetric shrinkage of coals estimated by the He-expansion method and by a bed-height technique ${ }^{23}$ along with the percent volume of moisture removed.

surface heterogeneity of the adsorbent. ${ }^{51,55}$ From these two parameters, the average pore sizes of coals can be calculated using Medek's approach ${ }^{51,55}$

$$
r_{\mathrm{e}}=\frac{\left(\frac{k}{E_{\mathrm{o}}}\right)^{\frac{1}{3}}}{\Gamma\left(\frac{3 j+1}{3 j}\right)}
$$

where $k\left(=3.145 \mathrm{~kJ} \mathrm{~nm}^{3} \mathrm{~mol}^{-1}\right.$ for $\left.\mathrm{CO}_{2}\right)$ is a constant ${ }^{55}$ and $\Gamma$ is the gamma function.

\section{Results and Discussion}

3.1. Volumetric Changes Due to Drying of Coals. Volumes of the as-received and dried Argonne Premium coals were measured using the helium expansion method. Figure 1a shows these specific volumes as a function of carbon content on a dry, ash-free basis (daf). The variation in the volumes of the dried coals was very modest, although a shallow maximum around $0.8 \mathrm{~cm}^{3} / \mathrm{g}$-coal, daf, could be seen at carbon contents between $78 \%$ and $80 \%$. In contrast, the volumes of the as-received coals decrease continuously from $1.25 \mathrm{~cm}^{3} / \mathrm{g}$ daf coal, at a carbon content of about $72 \%$, to $0.7 \mathrm{~cm}^{3} / \mathrm{g}$ daf coal, at a carbon content of about $92 \%$. The volumes of the as-received coals are consistently higher than the volumes of the dried coals. The difference is especially large for the low-rank coals. The volume change may be related to the shrinkage of the coal matrix and the collapse of the pore structure that occurs upon drying. ${ }^{22}$

The densities calculated from the specific volumes of the dried Argonne coals have been compared previously ${ }^{41}$ to the densities obtained by Huang et al. ${ }^{56}$ and Gan et al.,${ }^{57}$ and the agreement with the literature was found to be excellent.

(55) Debelak, K. A.; Schrodt, J. T. Fuel 1979, 58, 732-736.

(56) Huang, H.; Wang, K.; Bodily, D. M.; Hucka, V. J. Energy Fuels 1995, 9, 20-24.

(57) Gan, H.; Nandi, S. P.; Walker, P. L. Fuel 1972, 51, 272-277.
Figure $1 \mathrm{~b}$ shows the volume change of the coals upon drying as well as the volume of the removed water assuming a water density of $1 \mathrm{~g} / \mathrm{cm}^{3}$. As expected, the high-rank coals, which contain little moisture (Table 1), lose almost no water, whereas the low-rank coals, which have a high moisture content, lose a considerable amount of water. The volume change upon water removal is very small for the higher rank coals, whereas the volume change is significant for the coals with C\% below $80 \%$. As shown in Figure 1c, 2-5\% shrinkage was observed for the high-rank coals as a result of moisture loss and up to $40 \%$ shrinkage was observed for the low-rank coals. The volume change of the coals upon moisture loss estimated by the heliumexpansion method is always greater than the volume of water removed from coals (Figure 1b). The greater volume change is probably due to (1) the shrinkage of the coal matrix as a result of the water loss and (2) the increase in the accessibility of some pores to helium that were initially inaccessible.

Figure 1d compares the microscopic shrinkage obtained from the helium-expansion method, with the macroscopic shrinkage obtained by Suuberg et al. ${ }^{22,23}$ using a bed-height technique. The volume percent of the removed water is also included. The volume change measured by the heliumexpansion method is greater than the volume change estimated by the bed-height technique. The volume of removed water is about the same as the volume change estimated by the bed-height technique. The agreement is much better than would be expected based on the different volume losses being measured by the two techniques. In the case of Subberg, the volume loss upon drying reflects the shrinkage of the bed of particles. In the current case, the shape and size of the particles is irrelevant because He reports all of the available volume around, between, and within the individual pieces of coal. Thus, helium reports additional microscopic porosity that has been proposed as the root cause of the macroscopic shrinkage. As can be seen in Figure 1d, the extent of loss of microporosity is about twice the loss of macroscopic volume 

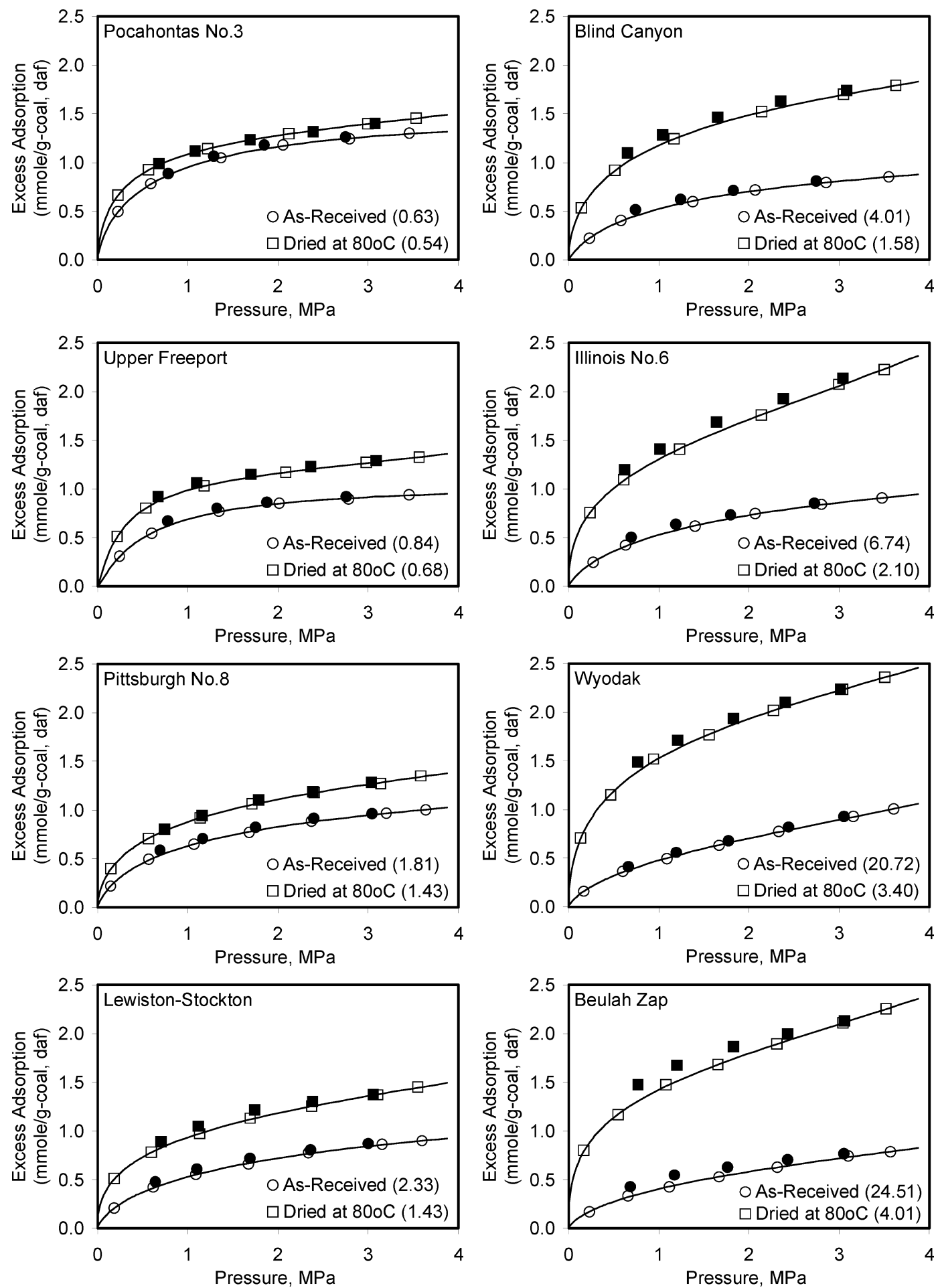

Figure 2. Adsorption (open symbols) and desorption (closed symbols) isotherms of $\mathrm{CO}_{2}$ on as-received and dried Argonne Premium coals (numbers in parentheses show the percent moisture content of coals).

(slope of 1.773 vs 0.863 ). The correlation with moisture loss is good for the low-rank coals in both cases but becomes poorer for the higher rank coals.

It is also important to note that the estimated volume changes measured by the two techniques are also crucial for accurate adsorption isotherm measurements. Changes in coal volume upon adsorption and desorption are not unique to water. It is well recognized that a number of compounds, including $\mathrm{CO}_{2}$, act as swelling agents for coals ${ }^{26,27,36,37}$ Shrinkage of up to $40 \%$ upon drying as well as swelling upon readsorption are important for the estimation of the adsorption isotherm because any volume change affects the experimentally calculated amount of excess adsorption. This demonstrates the need to rigorously control the volume of coals during the adsorption isotherm measurement or use an adsorption model, such as is presented in eq $2,{ }^{39}$ which allows for volume effects during the isotherm measurements.

3.2. Adsorption and Desorption Isotherms of $\mathrm{CO}_{2}$ on As-Received and Dried Argonne Premium Coals. Figure 2 shows the adsorption and desorption isotherms of $\mathrm{CO}_{2}$ on eight of the as-received and dried Argonne Premium coals. Numbers shown in parentheses are percent moisture content of coals. 
Table 2. Physical Constants Obtained by Fitting Eq 3 to the $\mathrm{CO}_{2}$ Adsorption Isotherms Shown in Figure 2

physical constants $^{a} \quad$ Pocahontas No. 3 Upper Freeport $\quad$ Pittsburgh No. 8 Lewiston Stockton Blind Canyon Illinois No. 6 Wyodak Beulah-Zap

\begin{tabular}{lcccc} 
& & \multicolumn{2}{c}{ as-received coals } \\
$n_{\mathrm{o}}$ & 1.31 & 0.91 & 0.91 & 0.88 \\
$E_{\mathrm{o}}$ & 23.0 & 21.3 & 20.7 & 18.5 \\
$j$ & 1.77 & 2.25 & 1.67 & 1.44 \\
$\Delta V$ & 0.07 & 0.06 & 0.11 & 0.08 \\
& & & dried coals at $80{ }^{\circ} \mathrm{C}$ for $36 \mathrm{~h}$ \\
$n_{\mathrm{o}}$ & 1.25 & 1.07 & 1.17 & 1.30 \\
$E_{\mathrm{o}}$ & 28.2 & 25.4 & 24.0 & 24.8 \\
$j$ & 2.0 & 2.7 & 1.6 & 1.3 \\
$\Delta V$ & 0.17 & 0.18 & 0.16 & 0.18
\end{tabular}

$0.88-0.78$

$18.5 \quad 19.5$

$1.44-1.72$

0.09

$1.30 \quad 1.65$

23.5

1.5

0.19

$\begin{array}{ccc}0.88 & 0.65 & 0.63 \\ 18.0 & 18.9 & 18.0 \\ 1.51 & 1.49 & 1.42 \\ 0.09 & 0.24 & 0.14 \\ & & \\ 1.52 & 1.97 & 1.72 \\ 27.0 & 25.4 & 28.8 \\ 1.5 & 1.5 & 1.4 \\ 0.49 & 0.34 & 0.40\end{array}$

${ }^{a} n_{\mathrm{o}}: \mathrm{mmol} / \mathrm{g}$-coal, daf. $E_{\mathrm{o}}: \mathrm{kJ} / \mathrm{mol} . \Delta V: \mathrm{cm}^{3} / \mathrm{g}$-coal, daf.

Lines are the best fit to the modified Dubinin-Astakhov equation, eq 3 . The rank and moisture contents of the coals are presented in Table 1. Pocahontas No. 3 is the highest rank coal and contained the least moisture $(0.65 \%)$. Upper Freeport, Pittsburgh No. 8, Blind Canyon, Lewiston Stockton, and Wyodak coals decrease in rank and increase in moisture content. Beulah-Zap is the lowest rank coal and contained the highest moisture content (32.24\%). Drying the coals at $80^{\circ} \mathrm{C}$ for $36 \mathrm{~h}$ under vacuum removed a smaller fraction of the total moisture content for the higher rank coals and a progressively larger fraction for the lower rank coals. For instance, the moisture content decreased from $0.65 \%$ to $0.54 \%$ (17\% of the initial moisture was removed) for Pocahontas No. 3, a high-rank coal, but decreased from $28.09 \%$ to $3.40 \%$ ( $88 \%$ removed) for the low-rank Wyodak coal. The effect of moisture removal was smaller for the higher rank coals than that for the lower rank coals. The adsorption isotherm of $\mathrm{CO}_{2}$ changed little for the high-rank Pocahontas No. 3 coal, but the original moisture content was small. On the other hand, significant increases in adsorption were obtained for the low-rank coals.

As shown in the figure, a small hysteresis was observed between the adsorption and desorption isotherms. Hysteresis was either nonexistent or negligible for high-rank and as-received coals; however, it was discernible for lower rank and dried coals. As noted before, the rectilinear form of the adsorption isotherm data fit the conventional adsorption equation poorly. ${ }^{39}$ However, the curves calculated from the best-fit solutions of the adsorption data to modified Dubinin-Astakhov equation (eq 3) gave excellent fits for all of the coals and these curves are presented in Figure 2. Equation 3 was used to extract the actual adsorbed amount from the excess isotherms. Simpler equations that are effective for rigid solids fail to account for volumetric inaccuracies caused by phenomenon such as gas solubility in the solid matrix and/or matrix swelling during the adsorption experiment (see Ozdemir ${ }^{39}$ for more discussion). Therefore, eq 3 was used to interpret the excess adsorption isotherms obtained for $\mathrm{CO}_{2}$ on the Argonne coals.

3.3. Variation of Physical Constants with Coal Rank and Moisture Content. Values of the physical constants adsorption capacity, characteristic heat of adsorption, Dubinin exponent, and volume effects $\left(n_{0}, E_{0}, j\right.$, and $\Delta V$, respectively) were obtained by fitting the observed excess $\mathrm{CO}_{2}$ adsorption data to the modified $\mathrm{D}-\mathrm{A}$ equation, eq 3 . The values are shown in Table 2.

3.3.1. Adsorption Capacity of $\mathrm{CO}_{2}$ on As-Received and Dried Argonne Coals. Figure 3 shows the adsorption capacity of $\mathrm{CO}_{2}$ on as-received and dried Argonne coals of different rank. Capacities were obtained by fitting eq 3 to the adsorption isotherm data displayed in Figure 2. As seen in the figure, the adsorption capacity is dependent on the moisture content of coals and varies with coal rank. The plot of adsorption capacity versus $\% \mathrm{C}$ gives the typical 'U-shape' curve for dried coals. The

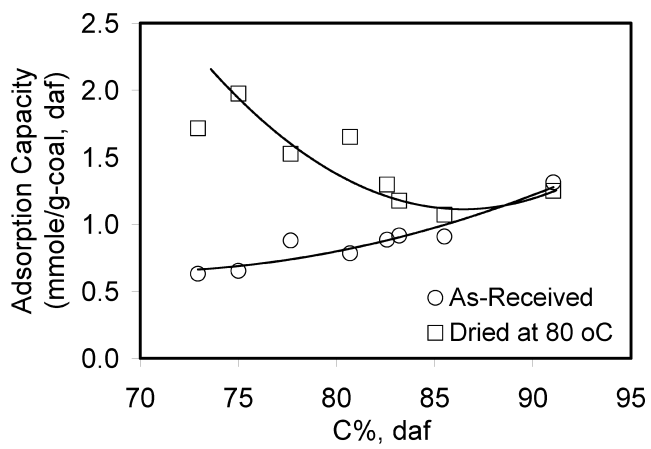

Figure 3. Adsorption capacity of as-received and dried Argonne Premium coals.

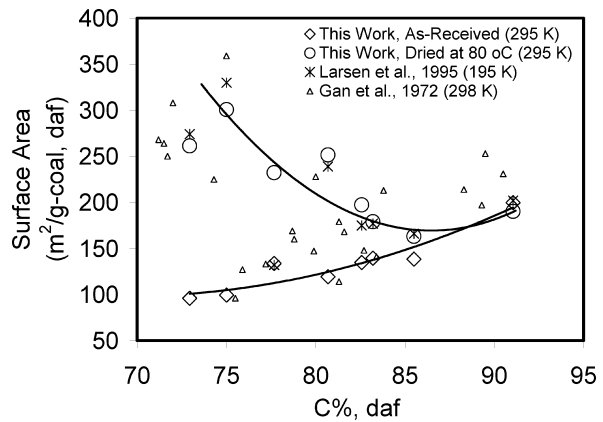

Figure 4. Surface area of as-received and dried Argonne coals compared to different rank of coals.

adsorption capacity decreases from about $2 \mathrm{mmol} / \mathrm{g}$-coal, daf, to about $1 \mathrm{mmol} / \mathrm{g}$-coal, daf, as the rank increases up to a carbon content of coals about $86 \%$ and then increases slightly as the carbon content further increases. However, the adsorption capacity increases almost linearly with rank for nondried, asreceived coals. For these coals, the adsorption capacity increases from about $0.6 \mathrm{mmol} / \mathrm{g}$-coal, daf, to about $1.3 \mathrm{mmol} / \mathrm{g}$-coal, daf.

3.3.2. Surface Areas of As-Received and Dried Argonne Coals. The surface areas of the as-received and dried Argonne coals were calculated from eq 4 using the $\mathrm{CO}_{2}$ adsorption capacities determined above which incorporated the full range of high-pressure data. Figure 4 shows these calculated surface areas together with literature values for the surface areas of the same (Larsen) or other (Gan) coals. Both sets of literature values were calculated using data obtained under traditional, lowpressure experimental conditions. ${ }^{44,57}$ Because the volumetric effects, including swelling, are small at low pressures, the literature data can be assumed to represent surface areas which are relatively free of error. ${ }^{39}$ The comparison in Figure 4 shows that the surface areas of the Argonne coals estimated from highpressure adsorption isotherms employing the modified D-A equation, eq 3, are in good agreement with the low-pressure values reported by Larsen et al. ${ }^{44}$ for the same set of dried 


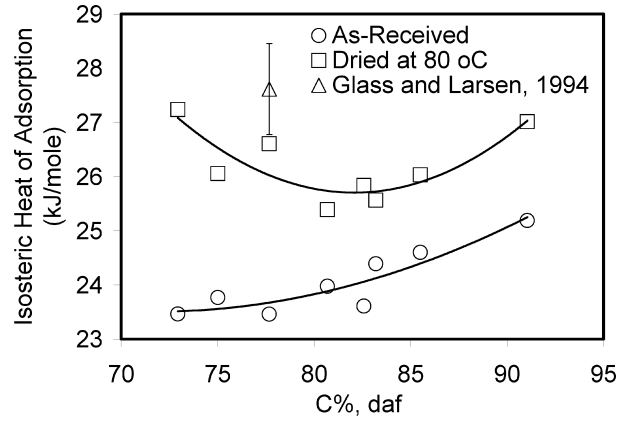

Figure 5. Isosteric heat of $\mathrm{CO}_{2}$ adsorption on as-received and dried Argonne Premium coals.

Argonne coals. Only Illinois No. 6 coal failed to give equivalent results for the dried form, appearing instead on our as-received curve. This is probably due to the different, and presumably less effective, drying procedure Larsen et al. ${ }^{44}$ indicated they used with this one specimen. Note that good agreement was obtained only if the volumetric effect, $\Delta V$, was taken into account. When the $\Delta V$ effects were not accounted for in the high-pressure data, the surface area estimates for the coals were $15-100 \%$ higher, with the low-rank and dried samples producing larger errors than their high-rank or nondried counterparts. Thus, for example, the as-received Pittsburgh sample gave a $15 \%$ error, while a $100 \%$ error was seen for the dried Wyodak sample if a rigid solid model was used.

The surface areas of the as-received coals were smaller than the surface areas of dried coals. The decrease in the surface area was especially significant for the lower rank coals, probably due to the accessibility of $\mathrm{CO}_{2}$ to those areas which were occupied and/or blocked by the water. The surface areas of nonArgonne coals of various ranks reported by Gan et al. ${ }^{57}$ appear to fall roughly along the two curves, some appearing closer to the dried Argonne coals and others appearing closer to the nondried samples. The spread of coal surface areas could be due to different extents of drying. For instance, Larsen et al. ${ }^{44}$ dried Argonne coals overnight at room temperature and $10^{-6}$ Torr, whereas Illinois No. 6 coal was dried in an all-glass vacuum apparatus at room temperature and $10^{-5}$ Torr. Gan et al. dried their coal samples at $130{ }^{\circ} \mathrm{C}$ for $1 \mathrm{~h}$ and then degassed at $130{ }^{\circ} \mathrm{C}$ and $10^{-5}$ Torr for $12 \mathrm{~h}$. It is clear that the degree of drying affects the adsorption capacity and the calculated surface area of coals. This indicates that the coal surface areas reported by different laboratories may be difficult to compare due to differences in the experimental procedures. ${ }^{58}$

3.3.3. Isosteric Heat of Adsorption. The isosteric heat of adsorption of $\mathrm{CO}_{2}$ was calculated from the characteristic heat of adsorption (Table 2) employing eq 5. As shown in Figure 5, the plot of isosteric heats of adsorption with carbon content is 'U-shaped' for dried coals displaying a distinct minimum at about $82 \%$ carbon and a corresponding heat of adsorption of about $25.3 \mathrm{~kJ} / \mathrm{mol}$. The range of heats of adsorption for these dried coals was small, between 25.3 and $27.3 \mathrm{~kJ} / \mathrm{mol}$, regardless of the coal rank. The isosteric heat of adsorption literature for the Argonne coal samples is limited, but the agreement between our value for the Illinois No. 6 using the modified D-A equation and that reported by Glass and Larsen ${ }^{59}$ using the inverse gas chromatography is very good (Figure 5). For the as-received coals, the isosteric heats of adsorption of $\mathrm{CO}_{2}$ display an almost

(58) Goodman, A. L.; Busch, A.; Duffy, G. J.; Fitzgerald, J. E.; Gasem, K. A. M.; Gensterblum, Y.; Krooss, B. M.; Levy, J.; Ozdemir, E.; Pan, Z.; Robinson, R. L.; Schroeder, K.; Sudibandriyo, M.; White, C. M. Energy Fuels 2004, 18, 1175-1182.

(59) Glass, A. S.; Larsen, J. W. Energy Fuels 1994, 8, 629-636.

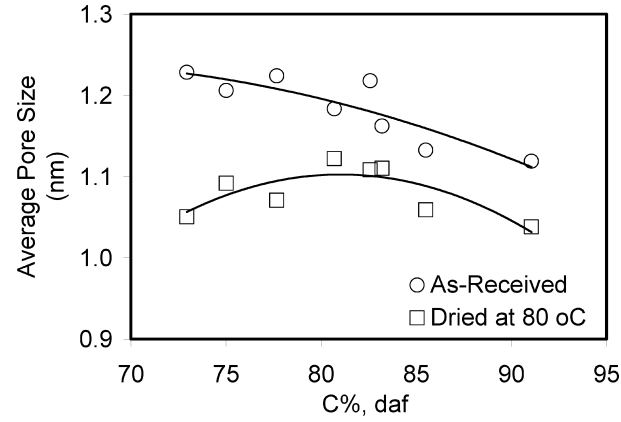

Figure 6. Average pore sizes of as-received and dried Argonne Premium coals estimated from $\mathrm{CO}_{2}$ adsorption isotherms at $22^{\circ} \mathrm{C}$.

linear shape with coal rank. The range of heats of adsorption for these coals was also small, between 23 and $25 \mathrm{~kJ} / \mathrm{mol}$, regardless of the coal rank. The range and magnitude of these isosteric heats of adsorption values suggests a physicaladsorption mechanism rather than a chemisorption mechanism.

3.3.4. Average Pore Size of As-Received and Dried Argonne Coals Measured by $\mathrm{CO}_{2}$. The average pore size of each as-received and dried Argonne coal was calculated using the Dubinin-Astakhov exponent, $j$ (Table 2), and the characteristic heat of adsorption, $E_{0}$, employing eq 6 . Figure 6 shows these average pore sizes. The pore size of the as-received coal shows a decreasing trend from 1.22 to $1.10 \mathrm{~nm}$ with increasing carbon content. On the other hand, the pore sizes of the dried coals were all calculated to be between 1.03 and $1.11 \mathrm{~nm}$ and exhibit a slightly raised maximum at about $82 \mathrm{C} \%$. The values calculated using eq 6 are lower than typical literature values. ${ }^{60,61}$ For example, Amarasekera et al. ${ }^{60}$ estimated the pore sizes of four brown coals, one medium-volatile subbituminous coal, one high-volatile subbituminous coal, and one low-volatile bituminous coal by $\mathrm{CO}_{2}$ adsorption and found the pore sizes to be $1.3-1.4 \mathrm{~nm}$, independent of coal rank. Radovic et al. ${ }^{61}$ reported the micropore sizes of coals estimated from the $\mathrm{CO}_{2}$ adsorption isotherms to be between 1.58 and $1.91 \mathrm{~nm}$. However, neither of these studies accounted for volumetric effects when analyzing the adsorption isotherms. If the volumetric contributions are ignored when analyzing the isotherms herein, the calculated average pore sizes increase to $1.15-1.55 \mathrm{~nm}$, similar to the ranges cited. As shown in Figure 6, the pore sizes of as-received coals are always higher than those of the dried coals, indicating that the pores collapse as a result of drying. This is consistent with the volumetric changes as shown in Figure 1 and with the ${ }^{1} \mathrm{H}$ NMR estimate of pore size using in situ pore water. ${ }^{29}$

3.3.5. Volumetric Effects. Figure 7 shows the change in volume for dried and as-received Argonne coals (Table 2), which were estimated from the adsorption isotherms of $\mathrm{CO}_{2}$ over the $4 \mathrm{MPa}$ range. The volume change for dried coals is ' $\mathrm{U}$-shaped' with rank, while it is nearly flat for the as-received coals. For dried coals, the volume change is about $60 \%$ for low-rank coals and about $20 \%$ for high-rank coals, whereas as-received coals exhibit a volume change of about $10 \%$, regardless of rank. As discussed previously, ${ }^{39,41}$ the $\Delta V$ term in eq 3 lumps together a number of effects including an apparent volume change due to the solubility of $\mathrm{CO}_{2}$ in the solid coal matrix, the actual swelling of the coal matrix, over- or underestimations of the skeleton volume of the coal sample due to the choice of helium to measure the void volume, and the sieving effect resulting from

(60) Amarasekera, G.; Scarlett, M. J.; Mainwaring, D. E. Fuel 1995, 74, 115-118.

(61) Radovic, L. R.; Menon, V. C.; Leon, Y. L.; Kyotani, T.; Danner, R. P.; Anderson, S.; Hatcher, P. G. Adsorption 1997, 3, 221-232. 


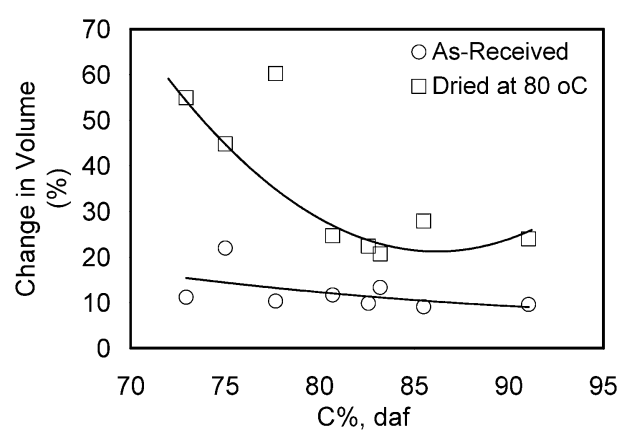

Figure 7. Estimated volume change of as-received and dried Argonne coals during the $\mathrm{CO}_{2}$ adsorption isotherm measurements at $4 \mathrm{MPa}$.

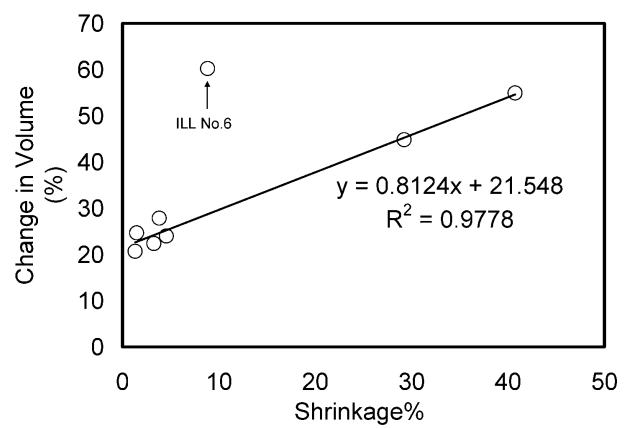

Figure 8. Comparison of the percent volume change estimated from the adsorption isotherms of $\mathrm{CO}_{2}$ on Argonne coals to the shrinkage of these coals as a result of the moisture loss estimated from the helium expansion method (volume change for Illinois No. 6 was not included in the regression analysis).

the different molecular dimensions of helium and $\mathrm{CO}_{2}$. The volume change for the as-received coals is smaller than the volume change for the dried coals, clearly indicating that moisture can play an important role in coal swelling.

Comparison of Figure 7 to Figure 1c shows that the trend in volume increases upon $\mathrm{CO}_{2}$ adsorption on dried coals is similar to the trend seen for volume decrease due to moisture loss. This can be seen even better by plotting the percent volume change, estimated from the adsorption isotherms of $\mathrm{CO}_{2}$, against the shrinkage resulting from the moisture loss as estimated from the helium expansion. This is shown in Figure 8. There is good agreement $\left(R^{2}=0.98\right)$ between the shrinkage due to moisture loss and swelling upon $\mathrm{CO}_{2}$ adsorption if the data for Illinois No. 6 are not included in the regression analysis. This implies that the volume lost during drying is recouped upon $\mathrm{CO}_{2}$ adsorption, i.e., both water and $\mathrm{CO}_{2}$ act as swelling agents for coal. However, $\mathrm{CO}_{2}$ is the more effective of the two, giving a volume change due to adsorption that is about $21 \%$ higher than the volume decrease due to moisture. Volume effects are the origin of the rectilinear shape of the adsorption isotherm at high pressures. When these effects were not included in the evaluation of the adsorption isotherm data, the estimated values of the physical constants (Table 2) in the absolute adsorption model equation were overestimated.

3.4. Quantifying the Effect of Moisture on Adsorption Capacity of Coals. In addition to the as-received and fully dried samples, isotherms were obtained for partially dried samples. Figure 9 shows the adsorption isotherms of $\mathrm{CO}_{2}$ obtained for the Argonne Premium Pittsburgh No. 8, Illinois No. 6, Wyodak, and Beulah-Zap coals, all of which were partially dried to intermediate moisture contents. The lines represent the best fit of the adsorption isotherm data to the modified $\mathrm{D}-\mathrm{A}$ equation, eq 3. As seen in the figure, lesser amounts of $\mathrm{CO}_{2}$ are adsorbed on moist coals. The amount of adsorbed $\mathrm{CO}_{2}$ appeared to increase as more and more moisture was removed.
The adsorbed $\mathrm{CO}_{2}$ on moist coals can be represented by the empirical equation, eq 1, developed originally by Ettinger et al. ${ }^{20}$ The linear form of eq 1 , which has been employed for the adsorption of $\mathrm{CH}_{4}$ on moist coals by Joubert et al., ${ }^{19}$ is

$$
\frac{n_{\mathrm{d}}}{n_{\mathrm{w}}}=A m+1 \quad\left(m \leq m_{\mathrm{c}}\right)
$$

There are reasons not to employ eq 7 to quantify the $\mathrm{CO}_{2}$ adsorption on moist coals. One is the difficulty in obtaining a coal sample totally free of moisture for the estimation of the adsorbed amount on the dried coal, $n_{\mathrm{d}}$, because removing the tightly bound 'unfreezable' water requires harsh conditions including higher temperatures which can alter the coal structure. ${ }^{62}$ Another is that, as discussed above, the adsorbed amount, $n_{\mathrm{w}}$ or $n_{\mathrm{d}}$, may be in error due to the effect of volumetric changes on the shape of the excess adsorption isotherm. In this case, the coefficient $(A)$ would vary with pressure, as described by Joubert et al. ${ }^{19}$ Here, we propose using the adsorption capacity of coals obtained from the best fit of the adsorption isotherms to eq 3 rather than the adsorbed amount, $n_{\mathrm{w}}$ or $n_{\mathrm{d}}$, at any one pressure. We slightly modified the Ettinger equation, eq 7, for the comparison such that

$$
\frac{1}{\left(n_{\mathrm{o}}\right)_{\mathrm{w}}}=\frac{A}{\left(n_{\mathrm{o}}\right)_{\mathrm{d}}} m+\frac{1}{\left(n_{\mathrm{o}}\right)_{\mathrm{d}}} \quad\left(m \leq m_{\mathrm{c}}\right)
$$

where $\left(n_{0}\right)_{\mathrm{w}}$ and $\left(n_{0}\right)_{\mathrm{d}}$ are the adsorption capacity of a moist and moisture-free coal estimated by fitting the adsorption isotherm data to the modified $\mathrm{D}-\mathrm{A}$ equation, eq 3 .

Figure 10a shows the linear relationship between the inverse of the adsorption capacity of the partially dried coals, $1 /\left(n_{\mathrm{o}}\right)_{\mathrm{w}}$, and their moisture content, $m$. Thus, the adsorption capacity of a moisture-free coal, $\left(n_{0}\right)_{\mathrm{d}}$, can be calculated as the reciprocal of the intercept and the Ettinger coefficient, $A$, from the slope and the intercept according to $A=$ slope/intercept. On the other hand, the linear relationship between the $\mathrm{CO}_{2}$ adsorption capacity of partially dried coals and their moisture content can be represented well by a linear relationship as

$$
\left(n_{\mathrm{o}}\right)_{\mathrm{w}}=\left(n_{\mathrm{o}}\right)_{\mathrm{d}}-\alpha m \quad\left(m \leq m_{\mathrm{c}}\right)
$$

where $\alpha$ is the slope of the linear relationship between the adsorption capacity of partially dried coals and their percent moisture content, in mmole of $\mathrm{CO}_{2}$ per gram of coal, daf, per percent moisture content (wt \%). As shown in Figure 10b, the $\mathrm{CO}_{2}$ adsorption capacity of partially dried coals, $\left(n_{\mathrm{o}}\right)_{\mathrm{w}}$, decreases linearly with moisture content, $m$. This is consistent with the reported $\mathrm{CH}_{4}$ adsorption on moist coals. . $^{415}$

Figure $10 \mathrm{c}$ and $10 \mathrm{~d}$ shows the comparison of the coefficient, $A$, in moisture $\%^{-1}$, and the slope, $\alpha$, in mmole of $\mathrm{CO}_{2}$ per gram of coal, daf, per percent moisture content (wt \%), and the adsorption capacity of moisture-free coals, $\left(n_{\mathrm{o}}\right)_{\mathrm{d}}$, obtained from eqs 8 and 9. As shown in Figure 10c, the coefficient values and the slope values vary with the coal rank. Although their values and units are different, they show a similar trend. Nevertheless, as shown in Figure 10d, the adsorption capacities of medium-rank moisture-free coals obtained using eq 9 are generally less than those obtained using eq 8 . The adsorption capacities of moisture-free coals obtained using eq 8 are higher and more scattered than the more consistent adsorption capacities that were obtained for the moisture-free coals employing eq 9. The deviations obtained using Ettinger et al.'s approach

(62) Norinaga, K.; Kumagai, H.; Hayashi, J.; Chiba, T. Energy Fuels 1998, 12, 574-579. 

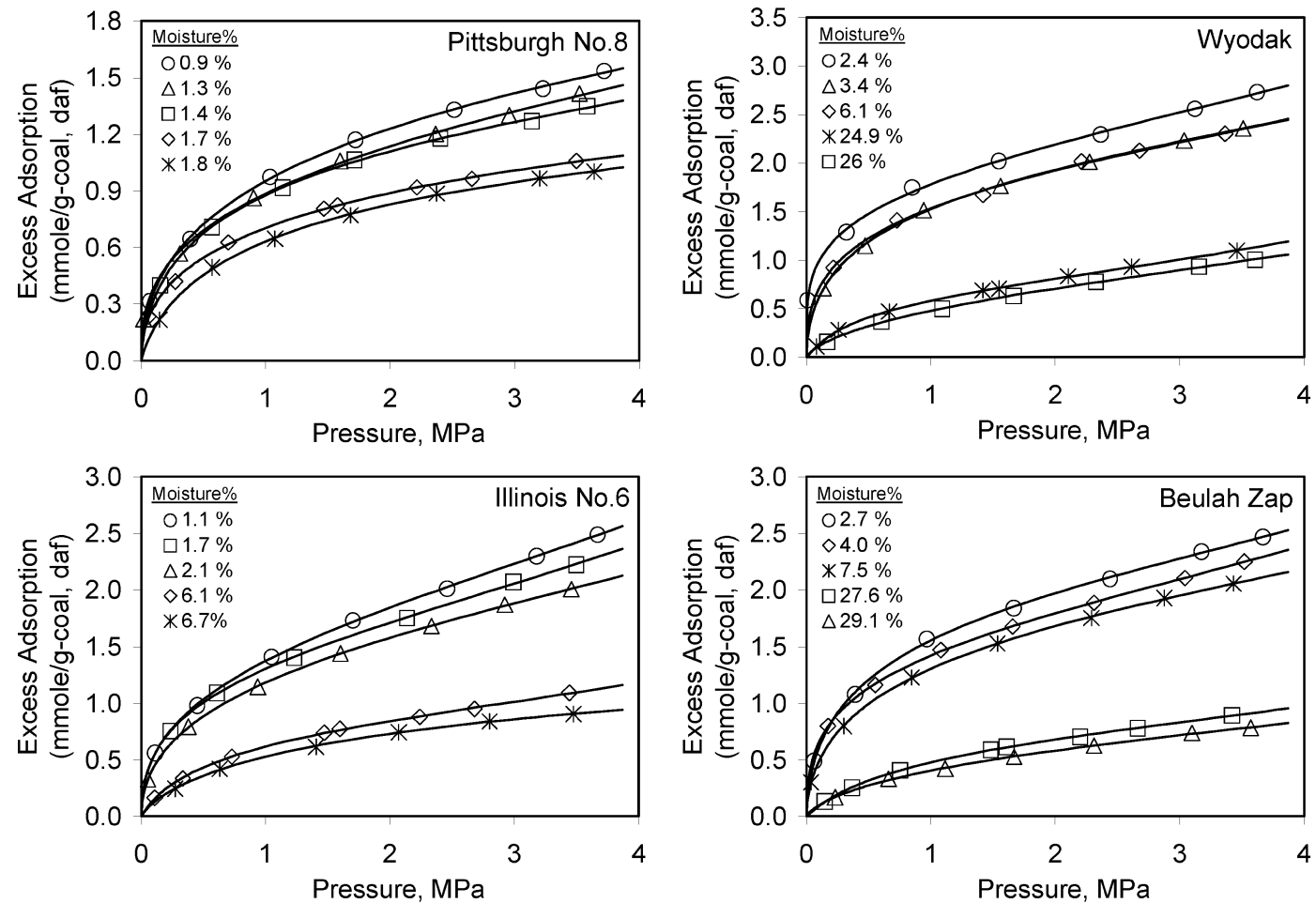

Figure 9. Adsorption isotherms of $\mathrm{CO}_{2}$ on selected partially dried Argonne coals.

(a)

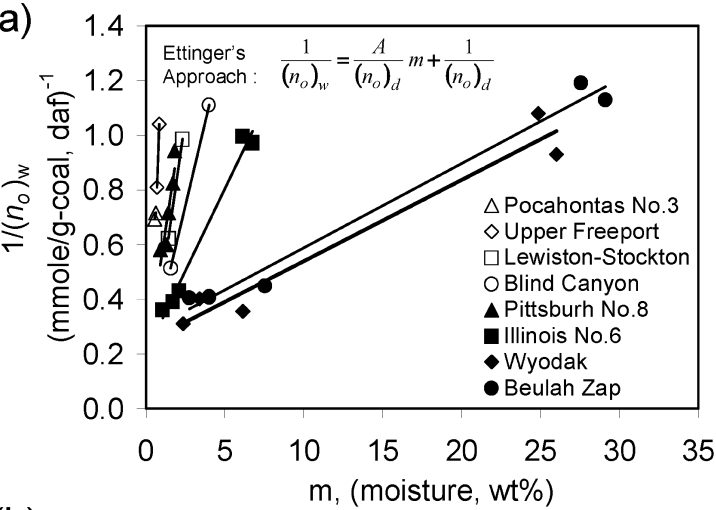

(b)

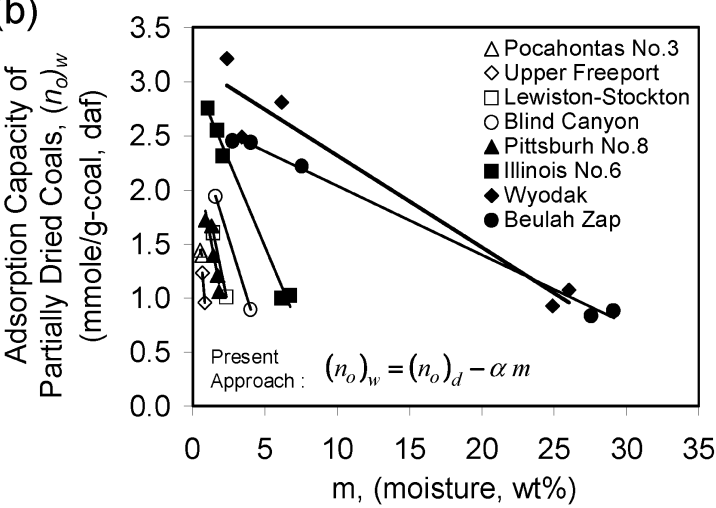

(c)
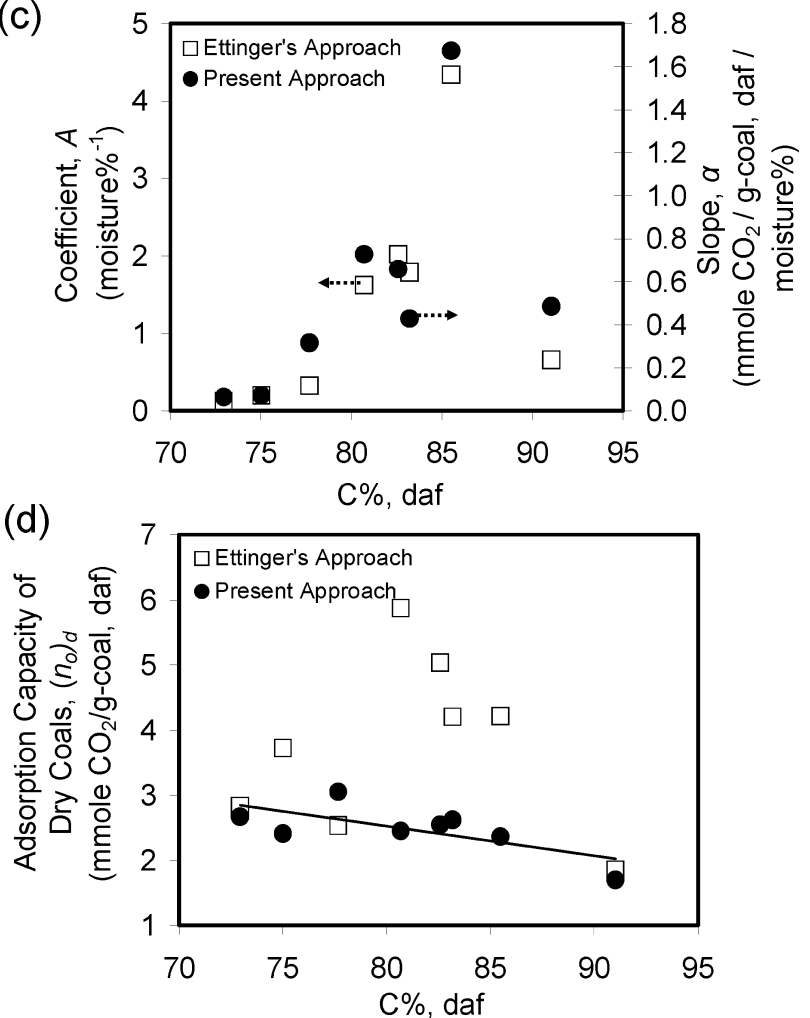

Figure 10. Effect of moisture content on the adsorption capacity of $\mathrm{CO}_{2}$ on coals. (a) Modified Ettinger's approach. (b) Present approach. (c) Comparison of the two approaches for the correlation coefficient $(A)$ and slope $(\alpha)$. (d) Comparison of the two approaches for the estimation of the adsorption capacity of the dried coals.

seem to be higher than those obtained using the present approach. Consequently, the adsorption capacity of moisturefree Argonne coals should be obtained from the linear relationship between the adsorption capacity of partially dried coals and their moisture contents, eq 9. Therefore, the ultimate adsorption capacity of moisture-free Argonne coals, which is an intrinsic property, is found to be about $2.6 \pm 0.7 \mathrm{mmol} / \mathrm{g}$ coal, daf basis.

The slopes $(\alpha)$ of the linear relationships between the adsorption capacity of the partially dried coals and their moisture contents in Figure 10b may provide information about the importance of water to the $\mathrm{CO}_{2}$ adsorption. Conversion of 


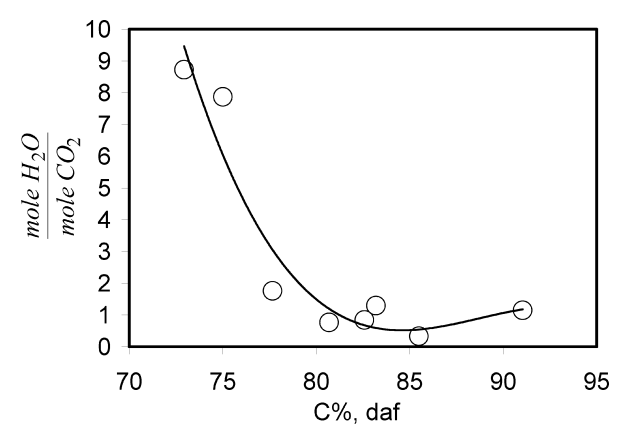

Figure 11. Estimated competition of $\mathrm{CO}_{2}$ with water for the adsorption sites on coal as moles of water lost per mole of $\mathrm{CO}_{2}$ adsorbed with coal rank.

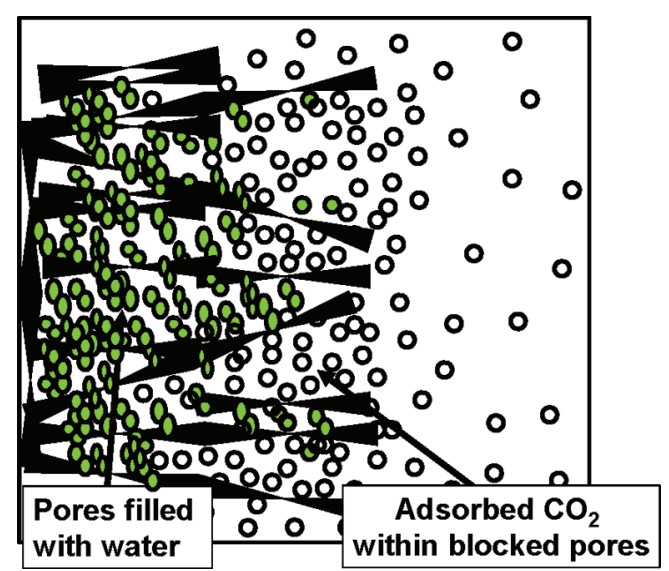

Figure 12. Proposed mechanism for $\mathrm{CO}_{2}$ adsorption on moist coals.

moisture contents of coals (wt \%), the grams of water per $100 \mathrm{~g}$ coal, to millimoles of water lost per gram of coal gives the slope of moles of water lost per mole of $\mathrm{CO}_{2}$ adsorbed. As shown in Figure 11, for the high-rank coals, the slopes appear to be between 0.8 and $1.2 \mathrm{~mol}$ of water lost per mole of $\mathrm{CO}_{2}$ adsorbed. Thus, the effect of moisture on the adsorption may be one of competition between $\mathrm{H}_{2} \mathrm{O}$ and $\mathrm{CO}_{2}$ for the same pore cavity or for the same binding site. However, the moles of water lost per mole of $\mathrm{CO}_{2}$ adsorbed becomes generally greater as one moves through the mid-rank to the low-rank coals. The slopes of the Wyodak and Beulah-Zap coals are about 8-9 mol of water lost per mole of $\mathrm{CO}_{2}$ adsorbed. Thus, in the case of low-rank coals, either many adsorption sites that are active for $\mathrm{H}_{2} \mathrm{O}$ adsorption are unfavorable for $\mathrm{CO}_{2}$ adsorption or water molecules form clusters, which may block the pore entrances and/or block the $\mathrm{CO}_{2}$ binding sites.

3.5. Implication to the Mechanism of $\mathrm{CO}_{2}$ Adsorption on Coals. Figure 12 illustrates a possible mechanism for $\mathrm{CO}_{2}$ adsorption on moist coals. In this mechanism, coal has a crosslinked layered macromolecular structure associated with both covalent and noncovalent interactions as evidenced by highresolution transmission electron microscopy (HRTEM) ${ }^{63,64}$ and wide-angle X-ray scattering (WAXRS) ${ }^{65}$ studies. ${ }^{66,67}$ Water is held within the coal either in free phase as bulk 'freezable' water or in adsorbed phase as tightly bound 'unfreezable' water. ${ }^{30,62}$ Because the pores are filled by the water, the only external

(63) Sharma, A.; Kyotani, T.; Tomita, A. Energy Fuels 2000, 14, 12191225.

(64) Sharma, S.; Kyotani, T.; Tomita, A. Energy Fuels 2000, 14, 515516.

(65) Wertz, D. L.; Quin, J. L. Fuel 2000, 79, 1981-1989.

(66) Painter, P. C.; Graf, J.; Coleman, M. M. Energy Fuels 1990, 4, $393-397$.

(67) Larsen, J. W.; Lee, D.; Shawver, S. E. Fuel Process. Technol. 1986, $12,51-62$. surface is exposed to the adsorbing gas. As shown in Figures 2 and 9, the adsorption capacity is smallest for wet coals and increases as more and more water is removed to form partially dried coals. As shown in Figure 7, $\mathrm{CO}_{2}$ does penetrate into the moist coals; therefore, the volume change is low. However, as water is removed from the pores, resulting in the shrinkage of the coal matrix (Figure 1a), $\mathrm{CO}_{2}$ can penetrate into these pores, partially restoring the coal volume, especially for the low-rank coals. As shown in Figure 5, the isosteric heat of adsorption for wet coals is smaller than that for dried coals, indicating that the adsorption occurs mostly on the outer portion of pores rather than within the inner portion of these pores where the surface potential for adsorption is high. ${ }^{53}$ From Figure 6, the average pore sizes are larger for moist coals than for the dried coals. The extent to which a swelling agent can dilate the coal pores depends on the relative abundance of covalent cross-links and secondary forces, such as hydrogen bonding, ionic interactions, and van der Waals interaction in the coal, and on the disruption or reassociation of these cross-links. ${ }^{68}$ As shown in Figure 1b, coals do shrink upon moisture lost. ${ }^{22}$ However, the degree of shrinkage is larger than the volume of the water removed. As shown in Figure 11, for the high-rank coals as moisture is removed from the coal structure, the available volume seems to be relatively unchanged and is filled by the adsorbing $\mathrm{CO}_{2}$ because the structure is more rigid and shrinkage of high-rank coals due to moisture loss is very small. On the other hand, when the moisture is removed from the low-rank coals, only part of the volume occupied by the removed water is reoccupied by $\mathrm{CO}_{2}$ and the rest of the volume is lost, probably because the structure has collapsed (relaxed). This is to be expected because, as shown in Figure 1d, the volume change (shrinkage) for the low-rank coals is high. Thus, because the preadsorbed water fills the pores in moist coals and occupies the pore space or the active sites for the adsorption, the $\mathrm{CO}_{2}$ cannot penetrate into those available sites for adsorption. As a result, lower adsorption capacities should be expected in wet coals.

3.6. Significance to $\mathrm{CO}_{2}$ Sequestration Modeling. Coal seams are naturally water saturated. Although the common practice in coalbed methane $(\mathrm{CBM})$ production is to withdraw the water from the coal seam to reduce the hydrostatic pressure, this only helps reduce the water in the cleat system but it is impossible to completely dry out the coal matrix with only pumping. Injection of $\mathrm{CO}_{2}$ can displace additional bulk water remaining in the cleat system, and it will also dry out the coal matrix, as is seen in the drying of powdered coal samples with supercritical $\mathrm{CO}_{2}$ under laboratory conditions. ${ }^{69}$ In $\mathrm{CO}_{2}$ sequestration/ECBM production, a moisture gradient along the coal seam and within the coal matrix will most likely occur. Because the presence of moisture significantly decreases the $\mathrm{CO}_{2}$ adsorption capacities of coals, $\mathrm{CO}_{2}$ adsorption isotherms of dried coals will provide only a portion of the information needed to interpret or model $\mathrm{CO}_{2}$ sequestration and that portion applies to the early stages when in situ supercritical drying is most likely. Later, when equilibrium conditions are reestablished, the moisture present in coal seam will successfully compete with the sorbed $\mathrm{CO}_{2}$ due to its higher heat of adsorption. ${ }^{70}$

\section{Conclusion}

Moisture plays an important role for the adsorption isotherms and adsorption capacity of $\mathrm{CO}_{2}$ on coals. Coals shrink upon

(68) Larsen, J. W.; Jones, J. Energy Fuels 2001, 15, 769-775.

(69) Iwai, Y.; Amiya, M.; Murozono, T.; Arai, Y.; Sakanishi, K. Ind. Eng. Chem. Res. 1998, 37, 2893-2896.

(70) Mahajan, O. P.; Walker, P. L. Fuel 1971, 50, 308-317. 
moisture loss. The extent of shrinkage estimated by the gasexpansion method is bigger than that of estimated by the bedheight technique. The adsorption capacities of dried coals give an U-shaped curve when plotted with respect to coal rank. Similar plots have been reported for a number of coal properties, such as surface area, ${ }^{40}$ porosity, ${ }^{57}$ and helium density of coals. ${ }^{56}$ On the other hand, the adsorption capacities of the wet coals is lower than that of the dried coals and shows an almost linear trend with coal rank. The presence of pore water reduces the adsorption capacity of $\mathrm{CO}_{2}$ either by blocking the path to or by occupying the adsorption sites within the coal matrix. Thus, we expect that the presence of water will significantly decrease the amount of $\mathrm{CO}_{2}$ stored in coal seams, which should be included in simulations of the ECBM production/ $\mathrm{CO}_{2}$ sequestration processes.

EF801126A 